\title{
Adverse effects of fractional laser
}

\section{Działania niepożądane lasera frakcyjnego}

\author{
Paulina A. Szczepanik-Kułak, Dorota Krasowska
}

Department of Dermatology, Venereology, and Paediatric Dermatology, Medical University of Lublin, Poland

Katedra i Klinika Dermatologii, Wenerologii i Dermatologii Dziecięcej, Uniwersytet Medyczny w Lublinie, Polska

Dermatol Rev/Przegl Dermatol 2019, 106, 634-645

DOI: https://doi.org/l0.5। |4/dr.2019.92736

\author{
CORRESPONDING AUTHOR/ \\ ADRES DO KORESPONDENCJI: \\ lek. Paulina A. Szczepanik-Kułak \\ Katedra i Klinika Dermatologii, \\ Wenerologii i Dermatologii \\ Dziecięcej \\ Uniwersytet Medyczny \\ w Lublinie, Polska \\ tel.: +485328415 \\ e-mail:vpaulinav@gmail.com
}

\begin{abstract}
The action of fractional lasers is based on the principle of fractional photothermolysis, which consists in generating in the skin a mesh of microthermal treatment zones surrounded by healthy, undamaged tissue. The most important factors determining the effectiveness of the procedure and the risk of developing adverse effects are: depth, size and density of microthermal treatment zones. The laser beam energy set by the operator is responsible for the depth of microthermal treatment zones penetration into the skin. The amount of intact, healthy tissue remaining between the micro damage zones and their depth depends on the number of laser beam passes. This draws attention to the need for careful selection of treatment parameters, which can only be performed by a person with appropriate qualifications. Fractional laser treatments are an effective form of therapy for many skin diseases and they have a low risk of side effects, most of which are short-term and harmless.
\end{abstract}

\section{STRESZCZENIE}

Działanie laserów frakcyjnych opiera się na zasadzie frakcyjnej fototermolizy, która polega na tworzeniu w skórze siatki punktowych stref cieplnego mikrouszkodzenia otoczonych zdrową, nieuszkodzoną tkanką. Najważniejszymi czynnikami determinującymi skuteczność zabiegu i ryzyko rozwoju działań niepożądanych są: głębokość, rozmiar i gęstość stref cieplnego mikrouszkodzenia, czyli liczba tych stref $\mathrm{w}$ przeliczeniu na jednostkę powierzchni skóry $\left(\mathrm{MTZ} / \mathrm{cm}^{2}\right)$. Za głębokość penetracji stref cieplnego mikrouszkodzenia do skóry odpowiada ustawiona przez operatora energia wiązki laserowej (mJ), natomiast od wykonanej liczby przejść wiązki laserowej zależy ilość nieuszkodzonej, zdrowej tkanki pozostającej pomiędzy strefami mikrouszkodzenia oraz ich głębokość. W związku z tym należy zwrócić uwagę na konieczność rozważnego doboru parametrów zabiegu, którego może dokonać jedynie osoba o odpowiednich kwalifikacjach. Zabiegi laserami frakcyjnymi są skuteczną formą terapii wielu chorób skóry, także u osób z ciemnym fototypem skóry, ponadto charakteryzują się niewielkim ryzykiem wystąpienia działań niepożądanych, z których większość jest krótkotrwała i niegroźna, dzięki czemu okres rekonwalescencji jest krótki i pacjent może szybko wrócić do codziennych aktywności.

Key words: complications, adverse effects, fractional laser.

Słowa kluczowe: powikłania, działania niepożądane, laser frakcyjny. 
In 2004 Manstein et al. revolutionized laser resurfacing by presenting a prototype device that was based on the principle of fractional photothermolysis. The device generates a point network of microthermal treatment zones (MTZs) with appropriate density $\left(\mathrm{MTZ} / \mathrm{cm}^{2}\right)$, size, and penetration into the skin [1, 2] (fig. 1). MTZs are surrounded with healthy intact tissue, in which regeneration associated with inflammatory and immunological mechanisms that leads to activation of epidermal stem cells begins. Thanks to that, the process of re-epidermalization is fast, and thus, shortens the time in which patients may return to their everyday activities $[3,4]$. The longest period of wound healing and the highest risk of adverse effects regards ablative laser with selective photothermolysis that lead to appearance of wide zones of epidermal vaporization and coagulation of the dermis. On the other hand, faster healing and limited risk of complication, especially infections, is associated with procedures involving fractional lasers, in which damage zones in the epidermis and dermis are minimal, and wide zones of healthy tissue are preserved $[1,3,5]$. Cohen et al. assessed the results of treating 730 patients, who had skin phototypes I-IV, with three different fractional lasers: erbium $1550 \mathrm{~nm}$, thulium $1927 \mathrm{~nm}$, and $\mathrm{CO}_{2}$. They noted $3.3 \%, 4.0 \%$, and $6.4 \%$ of complication in every group respectively, with no statistical difference $(p=0.26)$; the complications were mild and subsided after the introduced therapy. They showed that procedures involving fractional lasers are a satisfactory and safe therapy form for patients, including the ones with a dark skin phototype; moreover, they are characterized by a lower risk of adverse effects as compared with ablative lasers [6].

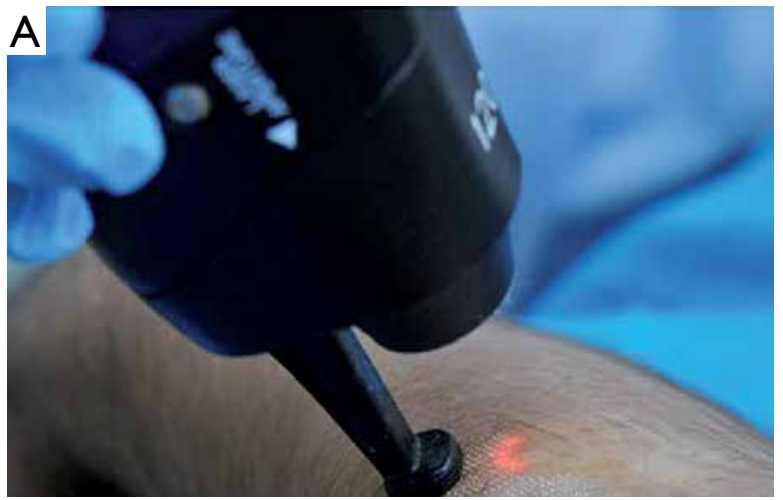

Figure I. A network of point micro-damages caused by fractional photothermolysis

Rycina I. Siatka punktowych mikrouszkodzeń powstała w wyniku frakcyjnej fototermolizy

\section{WPROWADZENIE}

W 2004 r. Manstein i wsp. zrewolucjonizowali lasoterapię, przedstawiając prototypowe urządzenie działające zgodnie z zasadą frakcyjnej fototermolizy. Polega ona na tworzeniu w skórze siatki punktowych stref cieplnego mikrouszkodzenia (microthermal treatment zones - MTZ) o odpowiedniej gęstości (MTZ/ $\mathrm{cm}^{2}$ ), średnicy oraz głębokości penetracji w głąb skóry [1, 2] (ryc. 1). Strefy MTZ otacza zdrowa, nieuszkodzona tkanka, w której rozpoczyna się regeneracja związana z mechanizmami zapalnymi i immunologicznymi prowadzącymi do aktywacji komórek macierzystych naskórka. Dzięki temu proces reepitelializacji przebiega szybko, co skraca czas powrotu chorego do codziennych aktywności [3, 4]. Najdłuższy okres gojenia i największe ryzyko wystąpienia działań niepożądanych dotyczą laserów ablacyjnych z selektywną fototermolizą, które powodują powstanie szerokich stref waporyzacji naskórka i koagulacji skóry właściwej. Najszybsze gojenie i ograniczone ryzyko rozwoju powikłań, zwłaszcza infekcyjnych, obserwuje się natomiast po zabiegach laserami frakcyjnymi, w których strefy uszkodzenia naskórka i skóry właściwej są minimalne i zachowane zostają szerokie strefy zdrowej tkanki $[1,3,5]$. Cohen i wsp. oceniali efekt leczenia 730 pacjentów z fototypami skóry od I do IV z zastosowaniem trzech różnych laserów frakcyjnych: erbowego $1550 \mathrm{~nm}$, tulowego $1927 \mathrm{~nm}$ oraz $\mathrm{CO}_{2}$. Stwierdzili odpowiednio 3,3\%, 4,0\% i 6,4\% powikłań w każdej z grup, bez różnicy statystycznej $(p=0,26)$, o łagodnym nasileniu, które ustąpiły pod wpływem wdrożonej terapii. Wykazali, że zabiegi laserami frakcyjnymi stanowią satysfakcjonującą dla pacjentów i bezpieczną formę terapii, także u osób z ciemnym fototypem skóry, ponadto charakteryzują się one mniejszym ryzykiem wystąpienia działań niepożądanych $\mathrm{w}$ porównaniu $\mathrm{z}$ laserami ablacyjnymi [6].

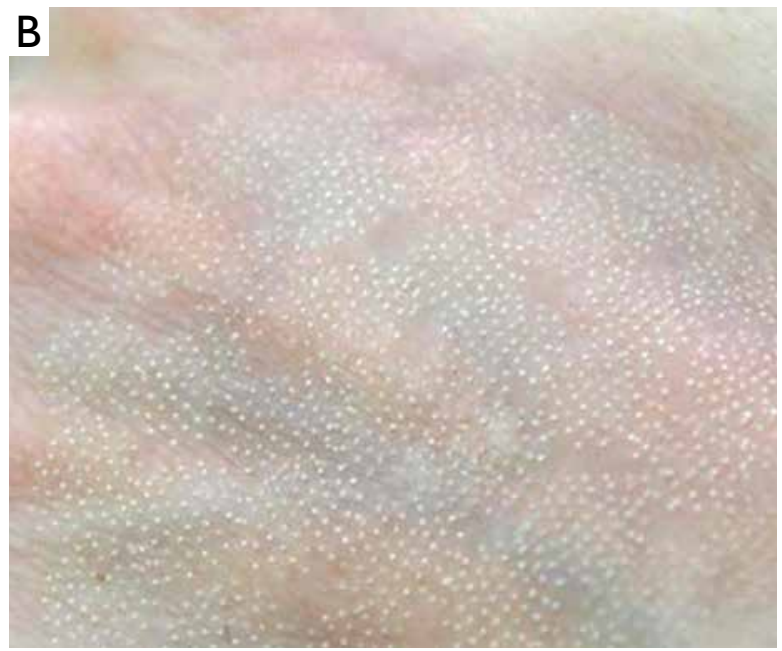


INDICATIONS FOR THE PROCEDURE AND TAKING PATIENT'S MEDICAL HISTORY PRIOR TO A THERAPY INVOLVING A FRACTIONAL LASER

Fractional lasers are currently used in therapies of numerous skin diseases thanks to little risk of adverse effects and high efficacy [7]. Kaushik and Alexis published guidelines for using fractional laser therapies together with the power of recommendations. The highest level (1b) was given to acne lesions and stretch marks, a little lower (2a) - scars, whereas moderate level (2b) was assigned to post-acne scars and chloasma [7].

Thorough medial history may significantly limit the risk of complications. It should include information about tolerance for previous laser procedures, disorders of wound healing, and presence of keloids, tendency to develop hyperpigmentations or frequent infections, including herpes. It is important to exclude topical or general infections, systemic connective tissue diseases, diabetes, addictions, diseases involving Köbner phenomenon, and to determine the drugs the patients has been and currently is taking. Exclusion criteria for laser therapy due to high disorder of wound healing include the use of oral isotretinoin and topical retinoids, six months and up to two weeks prior to the treatment respectively. There is no doubt that patient's written informed consent to undergo the planned procedure is of key importance [7-9]. Furthermore, assessment of the skin phototype according to the Fitzpatrick scale is significant, because patients with dark complexion show a higher tendency to develop post-inflammatory hyperpigmentations, hypertrophic scars and keloids, as compared with fair complexion [8]. It is recommended to gather information whether the patient prefers multiple procedures with a shorter healing time, or a lower number of procedures with a longer healing time, since that influences the procedure parameters [7]. Moreover, it should be determined whether patients have argyrosis in their medical history due to the fact that there had been reports concerning development of post-procedural complications in the form of dystrophic calcifications and ochronosis in a female patient, who had used dressings with silver [10].

\section{LASER THERAPY COMPLICATIONS DEPENDENT ON THE TECHNIQUE OF PERFORMING THE PROCEDURE}

The most important factors determining efficacy of the procedure and risk of adverse effects include: penetration, size, and density of microthermal treatment zones, i.e. the number of those zones per skin areas unit $\left(\mathrm{MTZ} / \mathrm{cm}^{2}\right)$. The laser beam energy $(\mathrm{mJ})$

\section{WSKAZANIA DO ZABIEGU I WYWIAD Z PACJENTEM PRZED PRZEPROWADZENIEM TERAPII Z ZASTOSOWANIEM LASERA FRAKCYJNEGO}

Lasery frakcyjne ze względu na niewielkie ryzyko wystąpienia działań niepożądanych oraz dużą skuteczność są obecnie stosowane w terapii wielu chorób skóry [7]. W pracy Kaushika i Alexisa opublikowano wskazania do zastosowania laseroterapii frakcyjnej wraz z siłą rekomendacji. Najwyższy stopień (1b) uzyskały wykwity trądzikowe i rozstępy skórne, nieco niższy (2a) - blizny, natomiast średni (2b) - blizny potrądzikowe i ostuda [7].

Dokładnie zebrany wywiad lekarski może znacznie ograniczyć ryzyko wystąpienia powikłań. Należy uzyskać informacje o tolerancji poprzednich zabiegów laserowych, zaburzeniach gojenia ran, obecności keloidów, tendencji do tworzenia przebarwień lub częstych zakażeń, w tym wirusami opryszczki. Istotne jest wykluczenie miejscowych lub ogólnych infekcji, układowych chorób tkanki łącznej, cukrzycy, nałogów, chorób z objawem Koebnera oraz ustalenie, jakie leki pacjent przyjmował w przeszłości i obecnie. Wśród kryteriów wyłączenia z laseroterapii ze względu na ryzyko zaburzenia gojenia ran znajduje się stosowanie izotretynoiny doustnie i retinoidów miejscowo, odpowiednio do 6 miesięcy i do 2 tygodni przed zabiegiem. Należy uzyskać pisemną, świadomą zgodę pacjenta na planowaną procedurę [7-9]. Ponadto istotna jest ocena fototypu skóry według Fitzpatricka, gdyż pacjenci z ciemną karnacją w porównaniu z jasną są bardziej podatni na tworzenie przebarwień pozapalnych, a także blizn przerostowych i keloidów [8]. Wskazane jest uzyskanie informacji, czy pacjent preferuje wielokrotne zabiegi z krótszym czasem gojenia czy ich mniejszą liczbę, ale związaną z wydłużonym okrtttesem gojenia, gdyż wpływa to na dobór parametrów zabiegu [7]. Ze względu na doniesienia o rozwoju powikłania pozabiegowego w postaci zwapnień dystroficznych oraz ochronozy u pacjentki, u której wcześniej na rany stosowano opatrunki ze srebrem, należy ustalić, czy w wywiadzie osobniczym występuje srebrzyca [10].

\section{POWIKŁANIA LASEROTERAPII ZALEŻNE OD TECHNIKI WYKONANIA ZABIEGU}

Najważniejszymi czynnikami determinującymi skuteczność zabiegu i ryzyko wystąpienia działań niepożądanych są: głębokość, rozmiar i gęstość mikrouszkodzeń cieplnych, czyli liczba tych stref w przeliczeniu na jednostkę powierzchni skóry $\left(\mathrm{MTZ} / \mathrm{cm}^{2}\right)$. Za głębokość penetracji MTZ do skóry odpowiada ustawiona przez operatora energia wiąz- 
set by the operator is responsible for the depth of MTZ penetration into the skin. The amount of intact, healthy tissue remaining between the micro damage zones and their depth depends on the number of laser beam passes $[8,11,12]$. Kono et al. showed that application of greater energy leads to deeper penetration of the laser beam, experiencing stronger pain during the procedure, and longer recuperation time. Then, choosing greater MTZ density resulted in appearance of oedema, erythema, and post-inflammatory hyperpigmentations that results from smaller distances of intact tissue [13]. With extension of pulse duration, thermal treatment zones become larger and may overlap, what in turn leads to complete skin ablation [11]. Duplechain showed that pulses shorter than 0.8 $\mathrm{ms}$ are not associated with the risk of spot overlap in case of the fractional laser. Yet, pulse duration over $0.8 \mathrm{~ms}$ may result in continual thermal skin damage and development of severe complications, such as extensive scarring [14]. In order to limit the risk of energy accumulation in tissues and complete ablation, one should avoid MTZ overlapping [12]. When only one area is treated, a subsequent laser beam should be directed perpendicularly with regard to the former one [15].

\section{PROCEDURAL ANAESTHESIA}

Available anaesthetic methods include: topical application of EMLA cream, lidocaine solutions injections into the area of the procedure, nerve block (especially when procedures involve orbital area), application of anaesthetic drops into the conjunctival sac, and both oral or intravenous anaesthetics [7]. Anaesthetic preparations applied onto the skin need to be removed prior to laser therapy, because there exist reports involving cases of patients who experienced systemic adverse effects, such as tingling around the mouth, tachycardia, palpitations, agitation, anxiety, and nausea after $30 \%$ gel lidocaine that had not been removed, during the fractional laser treatment [16]. Moreover, laser therapy of scars involves the risk of skin ulcers if superficial injections of an anaesthetic solution are trapped in the fibrous tissue and become the target of photothermolysis [17].

\section{DIVISION OF ADVERSE EFFECTS OF FRACTIONAL LASER TREATMENTS}

Considering the time when complications appear, there are early complications that appear within the first 7 days after the treatment. Those include: erythema, oedema, exudate, ecchymoses, contact dermatitis, and infections. Late complications include: post-inflammatory discolouring, scars, ectropion, ki laserowej (mJ). Od wykonanej liczby przejść wiązki laserowej zależy ilość nieuszkodzonej, zdrowej tkanki pozostającej pomiędzy strefami mikrouszkodzenia oraz ich głębokość [8, 11, 12]. Kono i wsp. wykazali, że zastosowanie większej energii wiąże się z głębszym przenikaniem wiązki laserowej, bardziej nasilonym odczuciem bólu w trakcie zabiegu i dłuższym czasem rekonwalescencji. Wybór większej gęstości MTZ skutkował wystąpieniem obrzęku, rumienia i przebarwień pozapalnych, wynikających z pozostawienia mniejszych odstępów nieuszkodzonej tkanki [13]. Wraz z wydłużeniem czasu trwania pulsu MTZ powiększają się i mogą nakładać się na siebie, co prowadzi do pełnej ablacji skóry [11]. Duplechain stwierdził, że w przypadku lasera frakcyjnego pulsy trwające poniżej 0,8 ms nie wiążą się z ryzykiem nakładania plamki, natomiast wydłużenie czasu trwania pulsu powyżej 0,8 ms może skutkować powstaniem ciągłego uszkodzenia cieplnego skóry i rozwojem ciężkich powikłań, takich jak rozległe bliznowacenie [14]. Aby ograniczyć ryzyko nagromadzenia energii w tkankach i pełnej ablacji, należy unikać nakładania się MTZ [12]. W przypadku terapii jednego obszaru kolejną wiązkę laserową powinno się kierować prostopadle do poprzedniej [15].

\section{ZNIECZULENIE DO ZABIEGU}

Wśród dostępnych metod znieczulenia wymienia się: miejscową aplikację kremu EMLA, ostrzyknięcie okolicy zabiegu roztworem lidokainy, blokadę nerwów (zwłaszcza w przypadku zabiegów w okolicy oczodołowej), podanie kropli znieczulających do worka spojówkowego, a także zastosowanie anestezji doustnej lub dożylnej [7]. Przed laseroterapią należy pamiętać o usunięciu nałożonego miejscowo na skórę preparatu znieczulającego, gdyż są doniesienia o pojawieniu się $\mathrm{w}$ trakcie leczenia laserem frakcyjnym hipopigmentacji i bliznowacenia niepożądanych objawów układowych, takich jak mrowienie wokół ust, tachykardia, kołatanie serca, pobudzenie, lęk oraz nudności, w przypadku nieusunięcia wcześniej 30\% żelu z lidokainą [16]. Ponadto podczas laseroterapii blizn istnieje ryzyko wystąpienia owrzodzeń skóry, jeśli powierzchowne wstrzyknięcia roztworu anestetyku ulegną uwięźnięciu w tkance włóknistej i staną się celem fototermolizy [17].

\section{PODZIAŁ DZIAŁAŃ NIEPOŻĄDANYCH ZABIEGÓW Z ZASTOSOWANIEM LASERA FRAKCYJNEGO}

Uwzględniając czas pojawienia się powikłań, wyróżnia się powikłania wczesne - występujące w czasie pierwszych 7 dni po zabiegu. Są to: rumień, 
milia, pustules, persistent erythema, and adhesions that develop after 1 week [12].

\section{Mild adverse effects}

Erythema, oedema and exudate (fig. 2) are the symptoms that occur temporarily in almost all patients after laser therapies and have diverse intensity. They indicate tissue damage and beginning of regeneration [7]. The following raised a red flag: too intense symptoms as compared with the parameters used during the procedure, prolonged time of lesions or their gradual intensification, appearance of pruritus, change of the erythema type into macular one, or change in the type of exudate from serous into purulent $[7,12]$.

Average duration of erythema is from 3 to 7 days, and in case of aggressive parameters, even up from 4 to 6 weeks [5]. Higher likelihood of long-term and intensified erythematous lesions regards patients with fair skin (skin phototype I and II), females, and areas covered in thin skin [15]. Apart from that nonsteroid anti-inflammatory drugs (NSAIDs), aspirin, vitamin $\mathrm{E}$, and preparation containing gingko extractions may induce or intensify erythematous lesions [18]. Ochi et al. showed that during subsequent laser procedures, pain and erythema are shorter and milder [19]. In case of intense erythematous lesions, topical application of weak glucocorticosteroids (e.g. ointment with $1 \%$ hydrocortisone, 2-4 times a day) or preparations containing ascorbic acid is recommended after the period of epithelialization [9, 20]. LED light efficacy was confirmed to lessen the intensity
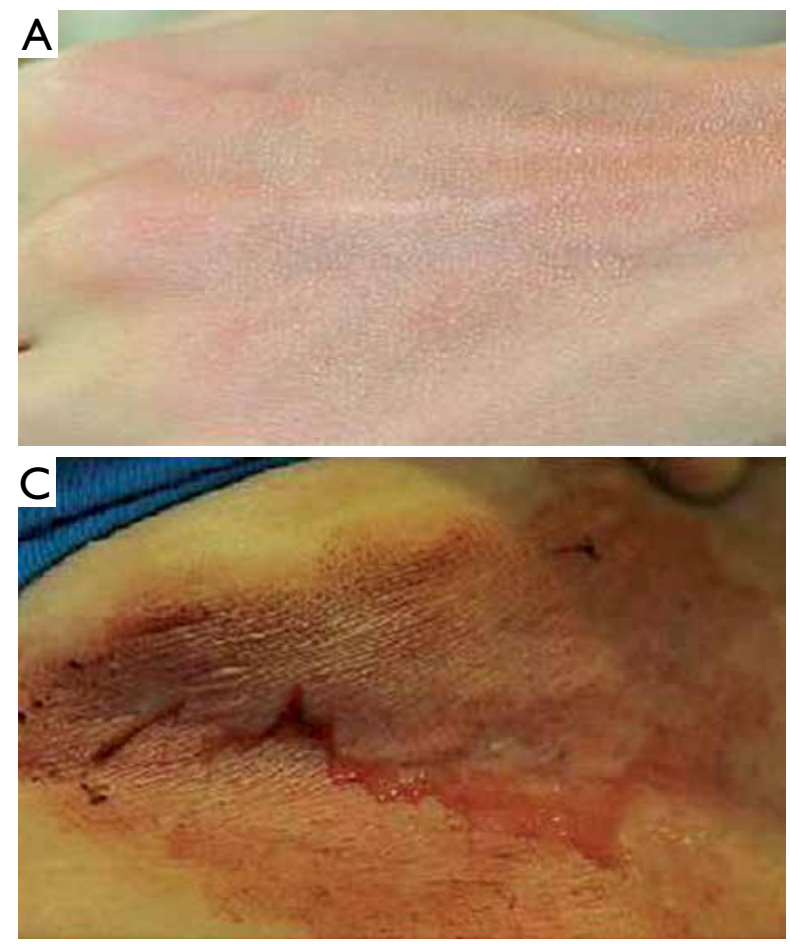

obrzęk, wysięk, wybroczyny, kontaktowe zapalenie skóry oraz infekcje. Powikłania późne, takie jak przebarwienia pozapalne, blizny, ektropion, prosaki, krosty, rumień przetrwały oraz zrosty, pojawiają się po upływie 1 tygodnia [12].

\section{Łagodne działania niepożądane}

Rumień, obrzęk i wysięk (ryc. 2) to objawy, które występują przejściowo $\mathrm{w}$ różnym nasileniu u prawie wszystkich pacjentów po zabiegach laserowych. Świadczą o uszkodzeniu tkanek oraz rozpoczynającej się regeneracji [7]. Niepokój budzi zbyt duże nasilenie objawów w stosunku do zastosowanych w trakcie zabiegu parametrów, przedłużone utrzymywanie się lub stopniowe nasilanie zmian, wystąpienie świądu, zmiana charakteru rumienia na plamisty lub rodzaju wysięku z surowiczego na ropny [7, 12].

Średni czas utrzymywania się rumienia wynosi 3-7 dni, a w przypadku zastosowania agresywnych parametrów nawet do 4-6 tygodni [5]. Większe prawdopodobieństwo długo utrzymujących się i nasilonych zmian rumieniowych dotyczy pacjentów z jasną cerą (I, II fototyp skóry), płci żeńskiej oraz okolic pokrytych cienką skórą [15]. Ponadto leki z grupy niesteroidowych leków przeciwzapalnych (NLPZ), kwas acetylosalicylowy, witamina $\mathrm{E}$ i preparaty zawierające wyciągi z miłorzębu japońskiego mogą indukować lub nasilać zmiany rumieniowe [18]. Ochi i wsp. wykazali, że w trakcie kolejnych zabiegów laserowych ból i rumień trwają krócej i są łagodniejsze [19]. W przypadku nasilonych wykwitów rumieniowych zaleca się miejscową aplikację słabych glikokortyko-

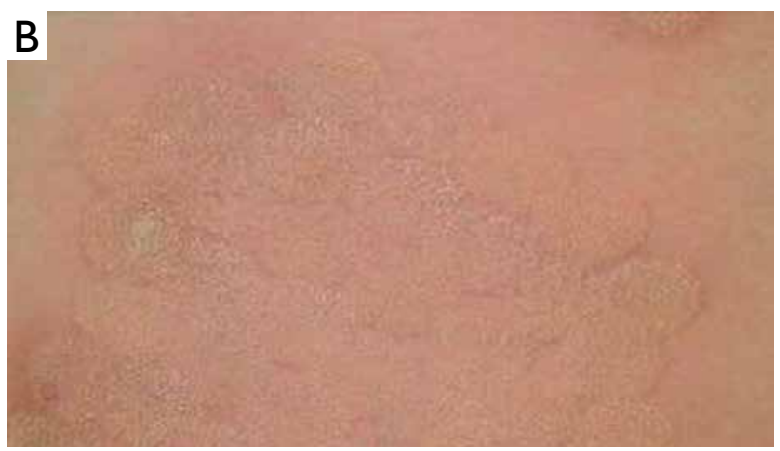

Figure 2. Erythema, oedema, exudate

Rycina 2. Rumień, obrzęk, wysięk 
and shorten the duration of erythematous skin lesions [21]. In case of persistent erythema, good therapeutic effects may be obtained after several procedures with a pulsed dyed laser (PDL) or intense pulse light (IPL) [9]. Interestingly, it may be possible to use a cream with probiotics in order to shorten the duration of post-procedural erythema and oedema [22].

Exudate is created due to epidermal damage and increased permeability of capillary vessels; it is rich in growth factors stimulating angiogenesis and regeneration processes. Absorption dressings as well as topical and/or general anti-inflammatory drugs are used to restrict its development. Ecchymoses (fig. 3) are most commonly found in the orbital region and may be a result of having used too high energy values for the thin skin in that region. In the post-procedural period it is important to recommended a temporary avoidance of taking NSAIDs and antiplatelet drugs as well as the ones that thin blood, because they may cause ecchymoses [5]. Pruritus may affect up to $90 \%$ of patients, who underwent a procedure with a fractional laser; it is usually present from 3 days to 3 weeks, and most often accompanies the process of wound healing. It may also be connected to skin dryness, crust formations, and irritation caused by topical application of preparations. Its presence always requires an infection to be excluded $[12,20]$. Cold water compresses or use of ice bags limit oedema and pruritus. Oral antihistamine drugs or mild anxiolytics may be used. In single cases with severe course, efficacy was obtained thanks to systemic steroid therapy (prednisolone $40-60 \mathrm{mg} /$ day for 3-5 days) [12, 23].

Inflammatory and non-inflammatory acne lesions may affect $2-10 \%$ of patients, and more often those patients that have positive medical history of acne lesions. Typically, they appear 1-2 weeks after the procedure [24]. Their formation results from direct activities - intrusion into the hair follicle structure by the laser beam, and indirect ones - use of comedogenic preparations, especially Vaseline or preparations with glucocorticosteroids [2]. Mild lesions are usu-

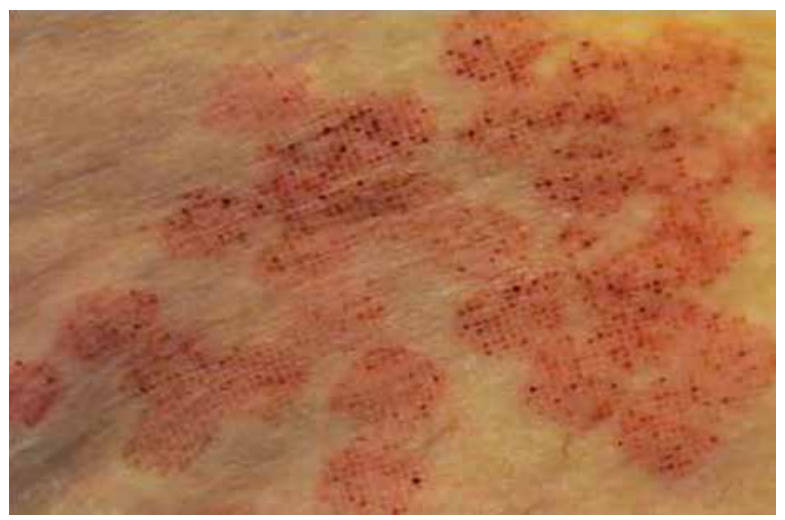

Figure 3. Ecchymoses

Rycina 3. Wybroczyny steroidów (przykładowo 1\% maść hydrokortyzonowa 2-4 razy dziennie) lub preparatów zawierających kwas askorbinowy po upływie okresu epitelializacji $[9,20]$. W zmniejszaniu intensywności i skracaniu czasu utrzymywania się wykwitów rumieniowych skuteczne okazało się światło LED [21]. W przypadku rumienia przetrwałego dobry efekt terapeutyczny można uzyskać po kilkukrotnych zabiegach laserem pulsacyjnym barwnikowym (pulsed dyed laser - PDL) lub impulsywnym źródłem światła (intense pulse light - IPL). [9] Ciekawa jest możliwość zastosowania kremu z probiotykiem, który skraca czas trwania pozabiegowego rumienia i obrzęku [22].

Wysięk powstaje w wyniku uszkodzenia naskórka i zwiększonej przepuszczalności naczyń włosowatych, jest bogaty w czynniki wzrostowe stymulujące angiogenezę i procesy regeneracji. Opatrunki absorpcyjne oraz miejscowo i/lub ogólnie stosowane leki przeciwzapalne służą do ograniczenia jego tworzenia. Wybroczyny (ryc. 3) najczęściej występują w okolicy oczodołowej i mogą wynikać z zastosowania zbyt dużej energii w stosunku do cienkiej skóry w tej lokalizacji. W okresie pozabiegowym istotne jest zalecenie tymczasowego unikania przyjmowania NLPZ oraz leków przeciwpłytkowych i przeciwzakrzepowych, które mogą wywoływać zmiany wybroczynowe [5]. Świąd może wystąpić nawet u 90\% pacjentów po zabiegu laserem frakcyjnym, średnio utrzymuje się od 3 dni do 3 tygodni i najczęściej towarzyszy procesowi gojenia rany. Może być także związany z suchością skóry, powstawaniem strupów, podrażnieniem wywołanym miejscową aplikacją preparatów. Jego obecność zawsze wymaga wykluczenia infekcji [12, 20]. W celu ograniczenia obrzęku i świądu stosuje się kompresy z zimnej wody lub przykładanie worków z lodem. Można zastosować doustne leki przeciwhistaminowe lub łagodne anksjolityki. W pojedynczych przypadkach o ciężkim przebiegu skuteczna okazała się glikokortykosteroidoterapia ogólna (prenizolon 40-60 mg/dobę przez 3-5 dni) [12, 23].

Wykwity trądzikowe zapalne i niezapalne moga wystąpić u 2-10\% pacjentów, częściej z dodatnim wywiadem osobniczym zmian trądzikowych. Zwykle pojawiają się w czasie 1-2 tygodni po zabiegu [24]. Ich powstawanie wynika $\mathrm{z}$ działania bezpośredniego - naruszenia struktury mieszków włosowych przez wiązkę lasera, lub pośredniego - stosowania preparatów komedogennych, zwłaszcza wazeliny, lub glikokortykosteroidowych [2]. Zmiany o łagodnym nasileniu zazwyczaj ulegają samoograniczeniu po zmianie maści i tłustych kremów, również zawierających filtry UV, na niekomedogenne preparaty nawilżające [20, 25-27]. W przypadku obecności zapalnych wykwitów trądzikowych zaleca się jak najszybsze włączenie antybiotykoterapii doustnej (tetracykliny lub doksycykliny), także profilaktycznie przed kolejnymi 
ally self-limiting after the change of ointment and rich creams that also contain UV filters into non-comedogenic moisturizing preparations [20, 25-27]. In case of inflammatory acne, it is recommended to start as soon as possible oral antibiotic therapy (tetracycline or doxycycline), also before subsequent procedures in order to prevent scarring [5]. If the general treatment brings clinical improvements, standard topical therapy should be started. It should be noted that isotretinoin is contraindicated due to the risk of developing hypertrophic scars in the tissue damaged by the laser beam $[20,28]$.

\section{Moderate adverse effects}

Contact dermatitis affects about $5-10 \%$ of individuals that undergo therapies with fractional lasers [12]. It is most often the result of irritation caused by make-up, topical moisturizing or peeling preparations, or perfumes. Clinical characteristics include the following symptoms during the first 4 weeks after the procedure: persistent erythema, blisters or erosions, sensation of skin burning, and pruritus [29, 30]. The patient should be instructed about the ban on mechanical irritation of the treated area, using makeup and cosmetic preparations only after the skin is fully healed [20, 26]. It is important to recommended avoidance of medicinal substances that are proved to increase the risk of contact dermatitis, such as neomycin, bacitracin, or polymyxin [9].

The risk of bacterial infection after a laser procedure is small; in ablative resurfacing it is estimated at $0.5-4.5 \%$, whereas in the fractional $-1-2 \%$ of procedures [31]. It was showed that in $20 \%$ of cases, occlusive dressing lead to the development of those infections; also, concomitant infections, lowered immunity, and topical application of non-sterile preparation during the wound healing process contribute to them $[12,20]$. Contagia include: Pseudomonas, Staphylococcus aureus, and Staphylococcus epidermidis that were confirmed in culture results in $41 \%, 35 \%$, and $29 \%$ of cases respectively [20]. However, there are reports concerning infections caused by nontuberculous mycobacteria [32, 33] or methicillin-sensitive Staphylococcus aureus (MSSA) strains that have a violent cause with accompanying general symptoms [34]. Bacterial infection symptoms usually develop within 1-3 days after the procedure and include: intensification of local pain or appearance of new pain, intense erythema, increased exudate, erosions, and crusts. Infections usually have a mild course and disappear fast after the introduction of target treatment $[12,20]$. Antibacterial prophylaxis is not routine due to low incidence of infections and risk of developing microorganism resistance [34]. Yet, it is recommended in individuals with immunosuppression and heart valve defects [12]. Proper behaviours before the zabiegami, aby nie dopuścić do powstania blizn [5]. Jeśli leczenie ogólne przyniesie poprawę kliniczną, powinno się rozpocząć standardową terapię miejscową. Należy zwrócić uwagę, że izotretynoina jest lekiem przeciwwskazanym ze względu na ryzyko rozwoju blizn przerostowych w uszkodzonej wiązką laserową tkance [20, 28].

\section{Umiarkowane działania niepożądane}

Kontaktowe zapalenie skóry dotyczy średnio 5-10\% osób poddawanych zabiegom laseroterapii frakcyjnej [12]. Najczęściej wynika z podrażnienia przez makijaż, miejscowe preparaty nawilżające, pilingujące lub perfumy. Klinicznie charakteryzuje się występowaniem w czasie pierwszych 4 tygodni po zabiegu takich objawów, jak utrzymujący się rumień, pęcherzyki lub nadżerki, uczucie palenia skóry, świąd $[29,30]$. Pacjent powinien zostać pouczony o zakazie mechanicznego drażnienia okolicy poddanej zabiegowi i możliwości nakładania makijażu i preparatów kosmetycznych dopiero po pełnym wygojeniu skóry [20, 26]. Istotne jest zalecenie unikania substancji leczniczych, co do których udowodniono, że zwiększają ryzyko wystąpienia kontaktowego zapalenia skóry, takich jak neomycyna, bacytracyna lub polimyksyna [9].

Ryzyko rozwoju zakażenia bakteryjnego po zabiegu laserowym uznaje się za niewielkie, w resurfacingu ablacyjnym ocenia się je na $0,5-4,5 \%$, natomiast we frakcyjnym - na 1-2\% zabiegów [31]. Stwierdzono, że w $20 \%$ przypadków jest ono spowodowane stosowaniem opatrunków okluzyjnych, sprzyjają mu także współistniejące infekcje, stan obniżonej odporności oraz miejscowa aplikacja niesterylnych preparatów w trakcie procesu gojenia $[12,20]$. Wśród drobnoustrojów chorobotwórczych wymienia się: Pseudomonas, Staphylococcus aureus, Staphylococcus epidermidis, które stwierdzono $\mathrm{w}$ wynikach posiewów w odpowiednio $41 \%$, 35\% oraz $29 \%$ przypadków [20]. Istnieją jednak doniesienia o zakażeniach wywołanych prątkami niegruźliczymi $[32,33]$ lub szczepami Staphylococcus aureus wrażliwymi na metycylinę (methicillin-sensitive Staphylococcus aureus MSSA) o gwałtownym przebiegu z towarzyszącymi objawami ogólnymi [34]. Wśród objawów zakażenia bakteryjnego, które zazwyczaj występują w czasie 1-3 dni po zabiegu, wymienia się: nasilenie miejscowych dolegliwości bólowych lub pojawienie się nowego bólu, intensywny rumień, zwiększony wysięk, nadżerki i strupy. Infekcje przebiegają zazwyczaj łagodnie i szybko ustępują po wdrożeniu celowanego leczenia $[12,20]$. Profilaktyka przeciwbakteryjna ze względu na niewielką częstość zakażeń i ryzyko rozwoju oporności mikroorganizmów nie jest wdrażana rutynowo [34]. Zaleca się ją jednak u osób z immunosupresją i wadami zastawkowymi serca [12]. 
procedure are of the essence - ban on applying cosmetic preparation or make-up on the skin that is to be treated with laser therapy, through sanitization of the operating field, and attention to aseptic rules during the procedure. Proper post-operative care include the use of occlusion dressings for the shortest required time, washing hands before application of topical preparations as well as dressings, and use of sterile ointments during the period of wound healing $[7,9]$.

Incidence of viral infections is estimated at $0.3-2 \%$ for fractional laser therapy, and for about $2-7 \%$ with full ablations; they most often are a result from reactivation of an infection with Herpes simples virus (HSV) [5, 7]. Symptoms usually appear during the first week after the procedure; superficial erosions are more often observed than blisters, what results from partial damage of the epidermis by the laser beam. Other symptoms include delayed wound healing, sensation of pruritus, or local disturbances of sensation [24,31]. Due to the risk of exacerbation, a viral infection is an absolute contraindication to perform the procedures [9]. Antiviral prophylaxis including aciclovir, valaciclovir or famciclovir 1-2 days before the procedure that is recommended to be continued up to 5-7 days after complete skin healing is believed to be obligatory for all patients with HSV infection in their medical history. In spite of these procedures, cases of herpes are reported [5]. Preventive treatment of healthy patients seems to be controversial. Some centres do not recommended it as a routine, what is a result of the infection's low incidence, whereas other centres recommend anti-viral drugs also for individuals without a positive HSV history [12, 26]. Graber et al. showed that routine prophylaxis against herpes infections should not be recommended. In a group of patients including 422 individuals, in whom 961 procedures were performed, $35 \%$ of HSV infections occurred despite proper prophylaxis, and $18 \%$ of infections developed in individuals without HSV in their medical history [25].

Mycotic infections are really rare. They are most often caused by Candida albicans, and typically appear 7-14 days after the procedure. Patients report the sensation of pruritus and local pain that are accompanied by erosions covered in white coating and surrounded by intense erythematous lesions or satellite lesions around the treated skin area [20]. In individuals with confirmed factors that could increase the risk of mycotic infections, prophylactic anti-mycotic treatment should be considered [35] (e.g. fluconazole $100 \mathrm{mg} 4$ times per day for 5 days) [12].

Post-inflammatory hyperpigmentation (PIH) (fig. 4) develops due to stimulation of melanocytes to produce pigment due to inflammation caused by tissue damage [36]. Clinically, there are two types: epidermal that often disappears spontaneously and responds to treatment better, and cutaneous that lasts longer and some-
Niezwykle istotne jest właściwe postępowanie przed zabiegiem - zakaz nakładania na skórę poddawaną laseroterapii preparatów kosmetycznych lub makijażu, dokładne odkażenie pola operacyjnego i dbałość o zachowanie zasad aseptyki w trakcie zabiegu. Właściwa opieka pooperacyjna zakłada stosowanie opatrunków okluzyjnych przez najkrótszy wymagany czas, dokładne mycie rąk przed nałożeniem preparatów miejscowych i opatrunków oraz stosowanie jałowych maści w okresie gojenia skóry [7, 9].

Częstość występowania wirusowych powikłań infekcyjnych ocenia się na 0,3-2\% w przypadku laseroterapii frakcyjnej, a przy pełnej ablacji na ok. 2-7\%. Najczęściej wynikają one z reaktywacji zakażenia wirusami opryszczki zwykłej (Herpes simplex virus HSV) $[5,7]$. Objawy zazwyczaj występują w pierwszym tygodniu po zabiegu, częściej obserwuje się powierzchowne nadżerki niż pęcherzyki, co wynika z częściowego uszkodzenia naskórka przez wiązkę laserową. Wśród innych objawów wymienia się: opóźnione gojenie rany, świąd lub miejscowe zaburzenia czucia [24, 31]. Ze względu na ryzyko zaostrzenia bezwzględnym przeciwwskazaniem do wykonywania zabiegów jest aktywna infekcja wirusowa [9]. Profilaktykę przeciwwirusową $\mathrm{w}$ postaci przyjmowania acyklowiru, walacyklowiru lub famcyklowiru 1-2 dni przed zabiegiem z zaleceniem kontynuacji do 5-7 dni po pełnym wygojeniu skóry uznaje się za obowiązkową u pacjentów z infekcją HSV w wywiadzie. Pomimo tego postępowania odnotowuje się przypadki zachorowań na opryszczkę [5]. Kontrowersyjne wydaje się zapobiegawcze stosowanie leków u osób zdrowych. Niektóre ośrodki nie zalecają go rutynowo, co wynika z nieznacznej częstości występowania zakażenia, inne $\mathrm{z}$ kolei rekomendują stosowanie leków przeciwwirusowych także u osób bez dodatniego wywiadu HSV $[12,26]$. Graber i wsp. wykazali, że rutynowa profilaktyka zakażenia wirusami opryszczki nie powinna być zalecana. W grupie 422 pacjentów, u których wykonano 961 zabiegów, 35\% infekcji HSV wystąpiło pomimo prawidłowej profilaktyki, a $18 \%$ u osób bez wywiadu HSV [25].

Powikłanie w postaci infekcji grzybiczej stwierdza się bardzo rzadko, najczęściej jest ono spowodowane przez drożdżaki Candida albicans, zwykle pojawia się ok. 7-14 dni po zabiegu. Pacjenci zgłaszają uczucie świądu i miejscową bolesność, którym towarzyszy obecność nadżerek pokrytych białym nalotem otoczonych intensywnymi zmianami rumieniowymi lub zmian satelitarnych wokół obszaru skóry poddanego zabiegowi [20]. U osób, u których występują czynniki zwiększonego ryzyka rozwoju infekcji grzybiczej, należy rozważyć profilaktyczne leczenie przeciwgrzybicze [35] (przykładowo flukonazol $100 \mathrm{mg} 4$ razy dziennie przez $5 \mathrm{dni}$ ) [12]. 


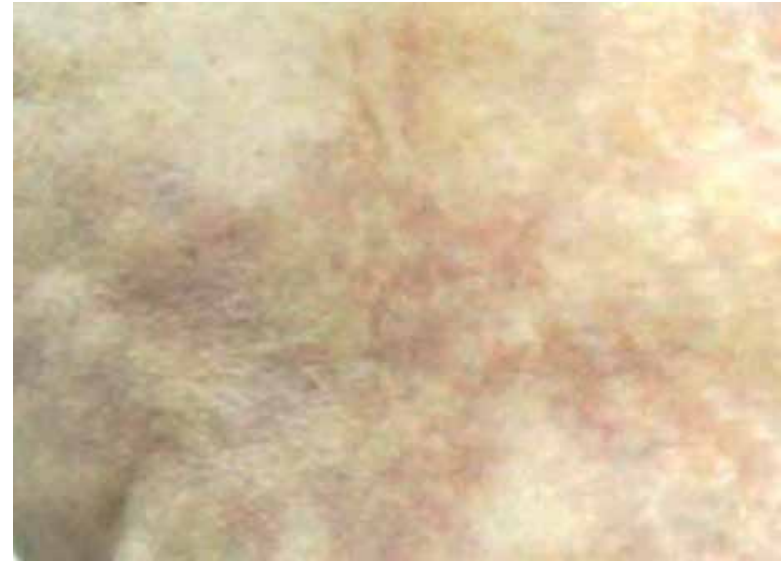

Figure 4. Post-inflammatory hyperpigmentation

Rycina 4. Przebarwienia pozapalne

times transforms into a chronic form. It is believed that $\mathrm{PIH}$ is the most common laser resurfacing complication in individuals with dark complexion [37]. Chan et al. showed that PIH incidence among Asian patients that underwent fractional laser procedures was 11.1-17.1\%. In case of procedures involving a fractional ablative laser, in individuals presenting skin phototype IV, $\mathrm{CO}_{2}$ reached even $92 \%$, whereas it was $23 \%$ for phototypes I-III [38]. Prophylactic methods include cautious choice of procedure parameters, especially MTZ density, which seems to play a more important role in $\mathrm{PIH}$ development than energy. Moreover, proper intervals between subsequent procedures should be maintained since they allow for disappearance of local inflammation, and, when needed, skin cooling (air, ice bags) may be used additionally during the laser therapy. It has not been confirmed whether topical illuminating preparations, glucocorticosteroids, preparations with epidermal growth factors, or oral tranexamic acid show efficacy in limiting the risk of developing post-inflammatory hyperpigmentations [39]. There exist reports that creams containing anti-inflammatory components (Licochalcone-A) decrease the risk of PIH development from the first day of being used [40]. Use of effective sunscreens against UV radiation, associated with limiting sun exposure and applying cream with at least SPF30, is an incredibly important guideline [41]. In patients with high risk of PIH development, such prophylaxis should be commenced 3 months before the laser therapy; in other cases - at least 8 weeks before the procedure. Preparations containing broad-spectrum sun filters should be applied after the skin heals completely, since the applications from the first day may lead to topical irritation [40]. Photoprotection is required to be continued for at least 6 weeks [12].

\section{Severe adverse effects}

One of the most serious complications of laser therapy is appearance of scars that most often develop due
Przebarwienia pozapalne (post-inflammatory hyperpigmentation - PIH) (ryc. 4) pojawiają się wskutek stymulacji melanocytów do produkcji barwnika pod wpływem stanu zapalnego wywołanego uszkodzeniem tkanki [36]. Klinicznie wyróżnia się dwie odmiany: naskórkową, często samoistnie ustępującą i lepiej odpowiadającą na leczenie, oraz skórną, która znacznie dłużej się utrzymuje i niekiedy przechodzi w formę przetrwałą. Uznaje się, że PIH to najczęstsze powikłanie resurfacingu laserowego u osób z ciemną karnacją [37]. Chan i wsp. wykazali, że częstość występowania PIH u osób pochodzenia azjatyckiego, u których wykonano zabiegi laserem frakcyjnym, wynosiła 11,1-17,1\%. W przypadku zabiegów ablacyjnym laserem frakcyjnym $\mathrm{CO}_{2}$ u osób z IV fototypem skóry sięgała ona aż $92 \%$, natomiast dla fototypów I-III oceniono ją na 23\% [38]. Wśród metod profilaktyki wymienia się ostrożny dobór parametrów zabiegu, szczególnie gęstości MTZ, która odgrywa ważniejszą rolę niż energia w powstawaniu PIH. Ponadto należy zapewnić odpowiednie odstępy czasowe pomiędzy kolejnymi zabiegami, co umożliwia ustąpienie miejscowego stanu zapalnego, a w razie potrzeby pozwala zastosować w trakcie laseroterapii dodatkowe chłodzenie skóry (powietrzem, workami z lodem). Nadal nie ustalono, czy miejscowe preparaty rozjaśniające, glikokortykosteroidowe, z naskórkowymi czynnikami wzrostu oraz doustnie stosowany kwas traneksamowy są skuteczne w ograniczaniu ryzyka rozwoju przebarwień pozapalnych [39]. Istnieją doniesienia, że stosowanie kremu zawierającego składniki przeciwzapalne (Licochalcone-A) od pierwszego dnia po zabiegu zmniejsza ryzyko rozwoju PIH [40]. Bardzo ważnym zaleceniem jest stosowanie skutecznej ochrony przed promieniowaniem UV, polegającej na ograniczeniu ekspozycji na słońce oraz używaniu kremów z filtrem co najmniej SPF 30 [41]. U pacjentów z wysokim ryzykiem rozwoju PIH taka profilaktyka powinna być rozpoczęta 3 miesiące przed laseroterapią, w innych przypadkach przynajmniej 8 tygodni przed zabiegiem. Preparaty zawierające szerokospektralne filtry przeciwsłoneczne należy nakładać po pełnym wygojeniu skóry, gdyż aplikacja od pierwszego dnia może prowadzić do miejscowych podrażnień [40]. Kontynuowanie fotoprotekcji wymagane jest przez minimum 6 tygodni [12].

\section{Ciężkie działania niepożądane}

Jednym z najpoważniejszych powikłań laseroterapii jest powstawanie blizn, które najczęściej są skutkiem niewłaściwego doboru parametrów lasera - zbyt wysokich wartości energii i gęstości stref uszkodzenia $\left(\mathrm{MTZ} / \mathrm{cm}^{2}\right)$, zbyt wielu przejść wiązki, nakładania się impulsów lub zbyt długiego czasu trwania pulsu [7, 9, 15, 42]. Bliznowacenie dotyczy najczęściej okolic o cienkiej skórze (głębsze przenikanie wiązki powoduje uszkodzenie warstwy siateczkowej) i ubogich w przydatki (wolniejsze gojenie) [42]. Wśród pozo- 
to improper laser parameters - too high energy values, MTZ density $\left(\mathrm{MTZ} / \mathrm{cm}^{2}\right)$, too many laser beam passes, impulse overlapping, or too long pulse duration $[7,9$, $15,42]$. Scarring most often regards areas of thin skin (deeper penetration of the beam leads to reticular layer damage) and adnexa-deficient areas (slower healing) [42]. Other risk factors include local infection or contact dermatitis, ontogenic tendency to develop keloids and hypertrophic scars, dark complexion, earlier irradiation, surgical procedures, dermabrasion or peelings, as well as use of oral isotretinoin 6 months before or 3 months after the procedures [30]. Experience of the person performing the procedure is also significant $[5,15,43]$. Symptoms of scar formation include: intense erythema, delayed healing (14-21 days), thickening of the tissue upon palpation, and sensation of pruritus. Clinically, it resembles inflammatory reaction, and consequently, it is recommended to collect wound culture in order to exclude infection $[5,14]$. Topical use of potent glucocorticoids or PDL procedures are recommended form of scar therapy [7, 42]. Prophylaxis includes cautious choice of parameters, especially during procedures performed in the following areas: oral cavity, mouth, neck, or upper chest [7, 42, 43].

\section{OTHER ADVERSE EFFECTS}

Reports on development of keratoacanthoma seem to be casuistic. Two patients, who had actinic keratosis foci on lower limbs, underwent laser therapy procedures in those areas. Then, after 4-6 weeks numerous hyperkeratotic papulae appeared that were diagnosed as keratoacanthoma on the basis of the histopathological examination. Perhaps, the lesions developed due to hair follicle damage during the procedure, or it was a manifestation of the Köbner phenomenon [44, 45]. Active phase of the skin disease including numerous Köbner phenomena is a contraindication for laser treatments, because the laser beam may lead to appearance of new lesions at the site of thermal treatment zones [9].

A small number of patients may suffer from skin hyperpigmentation caused by fractional photothermolysis. Factors that increase the risk of their development include ablation procedures in the past, and the use of topical preparations (hydroquinone and tretinoin) [36]. Treatment of the lesions may involve stimulation of melanogenesis with the use of PUVA therapy and peelings, thanks to which boarders of the disease regions become blurred [7, 12, 46, 47].

Ectropion, a condition in which the lower eyelid turns outwards, is caused by choosing too aggressive parameters with regard to the thin skin in this region, and the main risk factor of the lesion is blepharoplasty in patient's history. Treatment is recommended to include topical application of preparations with stałych czynników ryzyka wymienia się: miejscową infekcję lub kontaktowe zapalenie skóry, osobniczą skłonność do tworzenia keloidów i blizn przerostowych, ciemną karnację, wcześniejsze napromienianie, zabiegi chirurgiczne, dermabrazję lub pilingi oraz stosowanie doustnej izotretynoiny 6 miesięcy przed zabiegiem lub 3 miesiące po zabiegu [30]. Nie bez znaczenia jest brak doświadczenia osoby wykonującej zabieg [5, 15, 43]. Do objawów tworzenia się blizny należą: intensywny rumień, opóźnione gojenie (14$21 \mathrm{dni}$ ), wyczuwalne palpacyjnie stwardnienie tkanki, uczucie świądu. Klinicznie przypomina to toczącą się reakcję zapalną, w związku z czym zaleca się pobranie posiewu $\mathrm{z}$ rany $\mathrm{w}$ celu wykluczenia zakażenia $[5,14]$. Do zalecanych metod terapii blizn należą zastosowanie miejscowo silnych glikokortykosteroidów lub zabiegi laserem PDL [7, 42]. W profilaktyce zaleca się ostrożny dobór parametrów, zwłaszcza w trakcie zabiegów wykonywanych w okolicy oczodołów, ust, szyi lub w górnej części klatki piersiowej [7, 42, 43].

\section{POZOSTAŁE DZIAŁANIA NIEPOŻĄDANE}

Doniesienia o ryzyku rozwoju rogowiaka kolczystokomórkowego mają charakter kazuistyczny. U dwóch pacjentek, u których w obrębie kończyn dolnych występowały ogniska rogowacenia słonecznego, przeprowadzono w tej okolicy zabiegi laseroterapii. Po 4-6 tygodniach pojawiły się liczne hiperkeratotyczne grudki, które na podstawie wyników badania histopatologicznego rozpoznano jako rogowiaki kolczystokomórkowe. Być może rozwój zmian wynikał z uszkodzenia mieszków włosowych w trakcie zabiegu lub stanowił manifestację objawu Koebnera $[44,45]$. Aktywna faza choroby skóry, w której występują liczne objawy Koebnera, stanowi przeciwwskazanie do zabiegów laserowych, ponieważ wiązka laserowa może spowodować wysiew nowych zmian w miejscu cieplnego uszkodzenia skóry [9].

Powikłaniem frakcyjnej fototermolizy dotyczącym niewielkiej liczby pacjentów jest powstawanie odbarwień skóry. Wśród czynników zwiększających ryzyko ich wystąpienia wymienia się wykonywane w przeszłości zabiegi ablacyjne oraz stosowanie miejscowych preparatów (hydrochinonu i tretynoiny) [36]. W leczeniu zmian można uwzględnić stymulację melanogenezy z zastosowaniem PUVA-terapii oraz pilingi, dzięki którym zacierają się granice obszarów chorobowych [7, 12, 46, 47].

Za rozwój wywinięcia powieki, czyli ektropionu, odpowiada dobór zbyt agresywnych parametrów lasera w stosunku do cienkiej skóry tej okolicy, a głównym czynnikiem ryzyka powstania zmiany są zabiegi blefaroplastyki w wywiadzie. W leczeniu zaleca się miejscowo nakładane preparaty glikokortykosteroidowe (klobetazol), wstrzyknięcia triamcynolonu, a także 
glucocorticosteroids (clobetasol), triamcinolone injections, and eyelid massage by performing upward vertical movements with fingers $[5,9,42]$.

\section{CONCLUSIONS}

Fractional laser procedures are characterized by a small number of adverse effects, and the majority of them are short-term and harmless; thanks to that, the convalescence period is short. One of the most important factors allowing for limiting the risk of complications is cautious choice of procedure parameters that may be performed only by a person with proper qualifications. Simultaneously, the following are also important: patients' expectations and their informed consent, thorough collection of the medical history, full physical examination, proper behaviour before and after the procedure, as well as detailed outpatient guidelines. Careful monitoring of patients with regard to development of adverse effects allows for fast commencement of diagnostics and treatment.

\section{CONFLICT OF INTEREST}

The authors declare no conflict of interest. masaż powiek z wykonywaniem palcami pionowych ruchów w górę [5, 9, 42].

\section{PODSUMOWANIE}

Zabiegi laserem frakcyjnym charakteryzują się niewielką liczbą działań niepożądanych, z których większość jest krótkotrwała i niegroźna, dzięki czemu okres rekonwalescencji jest krótki. Jednym z najważniejszych działań pozwalających ograniczyć ryzyko występowania powikłań jest rozważny dobór parametrów zabiegu, który może przeprowadzić jedynie osoba z odpowiednimi kwalifikacjami. Jednocześnie ważne są: precyzyjne ustalenie oczekiwań pacjenta i uzyskanie jego świadomej zgody, wnikliwie zebrany wywiad, pełne badanie fizykalne, właściwe postępowanie przed zabiegiem i po nim oraz szczegółowe zalecenia ambulatoryjne. Uważna obserwacja pacjentów pod kątem rozwoju objawów niepożądanych pozwala na szybkie wdrożenie diagnostyki i leczenia.

\section{KONFLIKT INTERESÓW}

Autorzy nie zgłaszają konfliktu interesów.

\section{References \\ Piśmiennictwo}

1. Manstein D., Herron G.S., Sink R.K., Tanner H., Anderson R.R.: Fractional photothermolysis: a new concept for cutaneous remodeling using microscopic patterns of thermal injury. Lasers Surg Med 2004, 34, 426-438.

2. Fisher G.H., Geronemus R.G.: Short-term side effects of fractional photothermolysis. Dermatol Surg 2005, 31, 1245-1249.

3. Hantash B.M., Bedi V.P., Kapadia B., Rahman Z., Jiang K., Tanner H., et al.: In vivo histological evaluation of a novel ablative fractional resurfacing device. Lasers Surg Med 2007, 39, 96-107.

4. Hantash B.M., Mahmood M.B.: Fractional photothermolysis: a novel aesthetic laser surgery modality. Dermatol Surg 2007, 33, 525-534.

5. Metelitsa A.I., Alster T.S.: Fractionated laser skin resurfacing treatment complications: a review. Dermatol Surg 2010, 36, 299306.

6. Cohen S.R., Goodacre A., Lim S., Johnston J., Henssler C., Jeffers B., et al.: Clinical outcomes and complications associated with fractional lasers: a review of 730 patients. Aesthetic Plast Surg 2017, 41, 171-178.

7. Saedi N., Petelin A., Zachary C.: Fractionation: a new era in laser resurfacing. Clin Plast Surg 2011, 38, 449-461.

8. Kaushik S.B., Alexis A.F.: Nonablative fractional laser resurfacing in skin of color: evidence-based review. J Clin Aesthet Dermatol 2017, 10, 51-67.

9. Ramsdell W.M.: Fractional $\mathrm{CO}_{2}$ laser resurfacing complications. Semin Plast Surg 2012, 26, 137-140.

10. Shaub A.R., Brown P.J., Kobayashi T.T., Lewin-Smith M.R., Lupton G.P., Hivnor C.M.: Dystrophic calcification and accentuated localized argyria after fractionated carbon dioxide laser therapy of hypertrophic scars. JAMA Dermatol 2014, 150, $312-316$.

11. Waibel J., Beer K., Narurkar V., Alster T.: Preliminary observations on fractional ablative resurfacing devices: clinical impressions. J Drugs Dermatol 2009, 8, 481-485.

12. Costa F.B., El Ammar A.B., Campos V.B., Kalil C.L.: Complications in laser dermatologic surgery. Part II: fractional and nonfractional ablative laser and fractional non-ablative laser. Surg Cosmet Dermatol 2011, 3, 135-146.

13. Kono T., Chan H.H., Groff W.F., Manstein D., Sakurai H., Takeuchi M., et al.: Prospective direct comparison study of fractional resurfacing using different fluences and densities for skin rejuvenation in Asians. Lasers Surg Med 2007, 39, 311-314.

14. Duplechain J.K.: Severe neck scarring: a consequence of fractional $\mathrm{CO}_{2}$ laser resurfacing. J Cosmet Laser Ther 2016, $18,352-354$.

15. Hunzeker C.M., Weiss E.T., Geronemus R.G.: Fractionated $\mathrm{CO}_{2}$ laser resurfacing: our experience with more than 2000 treatments. Aesthet Surg J 2009, 29, 317-322.

16. Marra D.E., Yip D., Fincher E.F., Moy R.L.: Systemic toxicity from topically applied lidocaine in conjunction with fractional photothermolysis. Arch Dermatol 2006, 142, 1024-1026.

17. Chuang G.S., Manstein D., Tannous Z., Avram M.M.: Ulceration of mature surgical scars following nonablative fractional photothermolysis associated with intralesional lidocaine injections. Dermatol Surg 2012, 38, 1879-1881.

18. Fife D.J., Zachary C.B.: Delayed pinpoint purpura after fractionated carbon dioxide treatment in a patient taking ibuprofen in the postoperative period. Dermatol Surg 2009, 35, 553. 
19. Ochi H., Tan L., Tan W.P., Goh C.L.: Treatment of facial acne scarring with fractional carbon dioxide laser in Asians: a retrospective analysis of efficacy and complications. Dermatol Surg 2017, 43, 1137-1143.

20. Sullivan S.A., Dailey R.A.: Complications of laser resurfacing and their management. Ophthal Plast Reconstr Surg 2000, 16, 417-426.

21. Alster T.S., Wanitphakdeedecha R.: Improvement of postfractional laser erythema with light-emitting diode photomodulation. Dermatol Surg 2009, 35, 813-815.

22. Zoccali G., Cinque B., La Torre C., Lombardi F., Palumbo P., Romano L., et al.: Improving the outcome of fractional CO ${ }_{2}$ laser resurfacing using a probiotic skin cream: preliminary clinical evaluation. Lasers Med Sci 2016, 31, $1607-1611$.

23. Goldberg D.J.: Ablative lasers and devices. [In:] Laser dermatology - Pearls and Problems. D.J. Goldberg (ed.). Blackwell, New York, 2008, 126-138.

24. Carcamo A.S., Goldman M.P.: Skin resurfacing with ablative lasers. [In:] Cutaneous and Cosmetic Laser Surgery. M.P. Goldman (ed.). Elsevier, Philadelphia, 2006, 218-221, 227-288, 232-233.

25. Graber E.M., Tanzi E.L., Alster T.S.: Side effects and complications of fractional laser photothermolysis: experience with 961 treatments. Dermatol Surg 2008, 34, 301-305.

26. Campbell T.M., Goldman M.P.: Adverse events of fractionated carbon dioxide laser: review of 373 treatments. Dermatol Surg 2010, 36, 1645-1650.

27. Tanzi E.L., Wanitphakdeedecha R., Alster T.S.: Fraxel laser indications and long-term follow-up. Aesthet Surg J 2008, 28, 675678.

28. Alster T.S., Tanzi E.L., Lazarus M.: The use of fractional laser photothermolysis for the treatment of atrophic scars. Dermatol Surg 2007, 33, 295-299.

29. Lowe N J., Lask G., Griffin M.E.: Laser skin resurfacing. Pre- and posttreatment guidelines. Dermatol Surg 1995, 21, 1017-1019.

30. Zhang A.Y., Obagi S.: Diagnosis and management of skin resurfacing - related complications. Oral Maxillofac Surg Clin North Am 2009, 21, 1-12.

31. Setyadi H.G., Jacobs A.A., Markus R.F.: Infectious complications after nonablative fractional resurfacing treatment. Dermatol Surg 2008, 34, 1595-1598.

32. Berliner J.G., Aldabagh B., Mully T., Yu S.S., Schwartz B.S., Berger T.G.: Non-tuberculous mycobacterial infections following cosmetic laser procedures: a case report and review of the literature. J Drugs Dermatol 2015, 14, 80-83.

33. Culton D.A., Lachiewicz A.M., Miller B.A., Miller M.B., Mackuen C., Groben P., et al.: Nontuberculous mycobacterial infection after fractionated CO(2) laser resurfacing. Emerg Infect Dis 2013, 19, 365-370.

34. Xu L.Y., Kilmer S.L., Ross E.V., Avram M.M.: Bacterial infections following non-ablative fractional laser treatment: a case series and discussion. Lasers Surg Med 2015, 47, 128-132.

35. Alam M., Pantanowitz L., Harton A.M., Arndt K.A., Dover J.S.: A prospective trial of fungal colonization after laser resurfacing of the face: correlation between culture positivity and symptoms of pruritus. Dermatol Surg 2003, 29, 255-260.

36. Davis E.C., Callender V.D.: Postinflammatory hyperpigmentation a review of the epidemiology, clinical features, and treatment options in skin of color. J Clin Aesthetic Dermatol 2010, 3, 20-31.

37. Silpa-Archa N., Kohli I., Chaowattanapanit S., Lim H.W, Hamzavi I.: Postinflammatory hyperpigmentation: a comprehensive overview: epidemiology, pathogenesis, clinical presentation, and noninvasive assessment technique. J Am Acad Dermatol 2017, 77, 591-605.

38. Chan H.H., Manstein D., Yu C.S., Shek S., Kono T., Wei W.I.: The prevalence and risk factors of post-inflammatory hyperpigmentation after fractional resurfacing in Asians. Lasers Surg Med 2007, 39, 381-385.

39. Kaufman B.P., Aman T., Alexis A.F.: Postinflammatory hyperpigmentation: epidemiology, clinical presentation, pathogenesis and treatment. Am J Clin Dermatol 2018, 19, 489-503.

40. Wanitphakdeedecha R., Phuardchantuk R., Manuskiatti W.: The use of sunscreen starting on the first day after ablative fractional skin resurfacing. J Eur Acad Dermatol Venereol 2014, 28, 1522-1528.

41. Chaowattanapanit S., Silpa-Archa N., Kohli I., Lim H.W., Hamzavi I.: Postinflammatory hyperpigmentation: a comprehensive overview: treatment options and prevention. J Am Acad Dermatol 2017, 77, 607-621.

42. Fife D.J., Fitzpatrick R.E., Zachary C.B.: Complications of fractional $\mathrm{CO}_{2}$ laser resurfacing: four cases. Lasers Surg Med 2009, 41 , 179-184.

43. Avram M.M., Tope W.D., Yu T., Szachowicz E., Nelson J.S.: Hypertrophic scarring of the neck following ablative fractional carbon dioxide laser resurfacing. Lasers Surg Med 2009, 41, 185-188.

44. Mamelak A.J., Goldberg L.H., Marquez D., Hosler G.A., Hinckley M.R., Friedman P.M.: Eruptive keratoacanthomas on the legs after fractional photothermolysis: report of two cases. Dermatol Surg 2009, 35, 513-518 .

45. Gewirtzman A., Meirson D.H., Rabinovitz H.: Eruptive keratoacanthomas following carbon dioxide laser resurfacing. Dermatol Surg 1999, 25, 666-668.

46. Davis E.C., Callender V.D.: Postinflammatory hyperpigmentation a review of the epidemiology, clinical features, and treatment options in skin of color. J Clin Aesthetic Dermatol 2010, 3, 20-31.

47. Griffin A.C.: Laser resurfacing procedures in dark-skinned patients. Aesthet Surg J 2005, 25, 625-627.

Received: 19.02 .2019

Accepted: 19.10 .2019

Otrzymano: 19.02.2019 r.

Zaakceptowano: 19.10.2019 r.

How to cite this article

Szczepanik-Kułak P.A., Krasowska D.: Adverse effects of fractional laser. Dermatol Rev/Przegl Dermatol 2019, 106, 634-645. DOI: https://doi.org/10.5114/dr.2019.92736. 